Plato's Persona 
This page intentionally left blank 


\title{
Plato's Persona
}

\author{
Marsilio Ficino, \\ Renaissance Humanism, \\ and Platonic Traditions
}

Denis J.-J. Robichaud

\author{
$\overline{\text { PENN }}$ \\ UNIVERSITY OF PENNSYLVANIA PRESS \\ PHIL A DEL PHIA
}


Copyright (@) 2018 University of Pennsylvania Press

All rights reserved. Except for brief quotations used for purposes of review or scholarly citation, none of this book may be reproduced in any form by any means without written permission from the publisher.

$$
\text { Published by }
$$

University of Pennsylvania Press

Philadelphia, Pennsylvania 19104-4II2

www.upenn.edu/pennpress

Printed in the United States of America on acid-free paper I 355779 10 86642

Library of Congress Cataloging-in-Publication Data Names: Robichaud, Denis J.-J.

Title: Plato's persona : Marsilio Ficino, Renaissance humanism, and Platonic traditions / Denis J.-J. Robichaud.

Description: Ist edition. | Philadelphia : University of

Pennsylvania Press, [2018] | Includes bibliographical references and index.

Identifiers: LCCN 2017033924

ISBN 978-0-8122-4985-9 (hardcover : alk. paper)

Subjects: LCSH: Ficino, Marsilio, I 433-I499. |

Plato. | Philosophy, Renaissance. | Humanism-Italy. |

Platonists-Italy.

Classification: LCC B785.F434 R63 2018 | DDC 186/.4-dc23

LC record available at https://lccn.loc.gov/2017033924 
For Viveca 
This page intentionally left blank 